\title{
Research on the Improvement of People's Jury System under the Background of Judicial Justice
}

\author{
Bo Han \\ School of Civil and Commercial Law \\ Shandong University of Political Science and Law \\ Jinan, China
}

\begin{abstract}
The people's jury system has existed for more than 60 years in our country. It has made many beneficial contributions to the perfection of our judicial operation system and promotion of the judicial justice. However, with the development of the times, it has encountered a lot of unprecedented problems in practice. On the Fourth Plenary Session of the Eighth National People's Congress, it put forward to improve the people's jury system and strengthen the judicial justice. Therefore, it is necessary to carry out a thorough review of the existing people's jury system and put forward a perfect path according to the new requirements of strengthening judicial justice.
\end{abstract}

\section{Keywords—judicial justice; people's jury; perfection}

\section{INTRODUCTION}

Since the implementation of the separate law related to People's Jury System, the "Decision on Improving People's Jury System" on May 1, 2005, the People's Jury System in our country has made a great achievement. However, the People's Jury System which displays the public opinions has had few voices in the cases with great influence in recent years such as "Guangzhou Xu Ting case" and "Nanjing Peng Yu case". On the contrary, the public has shown great concern for the above cases, "Guangzhou Xu Ting case" was named 2007 Top Ten influential cases by the Southern Weekly; "Nanjing Peng Yu case" sparked widespread public debate in the country, and the public invariably questioned the judiciary authorities strongly in both the above cases. In other words, the People's Jury System which is supposed to represent the public opinions can not really play the role of communicating with the public opinion and judiciary, and the public's voices or public opinions have not been reflected in the current judicial system through the people's jury system. Justice is the most fundamental expectation of the public to judiciary. Most of the public is not a legal expert, but they have their own simple knowledge of justice. When there was no participation of public representative in the judicial decision process of the above cases, and the results of the judgments were inconsistent with the expectations of the majority of the public, the public would instinctively think that there was unfair phenomenon like "black-box operation" in the judicial decision of the above cases, which would obviously leave an expression of injustice

This paper is the mid-term result of Project of the Law Society of Shandong Province in 2016, "Research on the Improvement of People's Jury System under the Background of Judicial Justice" (Project No. SLS (2016) E43). on the judicial decision of the above cases, and the image of justice would be greatly damaged in the public mind. The judicial authority comes from the people's faith in judicial justice. The establishment of a nation's rule of law comes from the people's real experience of specific legal systems. As a judicial system for the public to participate in judiciary, the People's jury system itself is the result of judicial democratization. In addition, it expands the range of insiders of the judicial decision-making level, with the participation of jurors representing certain social levels, it can supervise and restrict the specialized judge to some extent; besides, as ordinary people, the people's jurors understand the conditions of the people and represent the public opinion, which can strengthen the people's connection with judiciary, enhance the public's sense of identity to judiciary, expand the scope of public awareness to judicial activities. Many studies have shown that the people's jury system, through the ordinary people's participation in case hearing, has played a role in power balance, judicial publicity, judicial independence and legal advocacy. These functions or values of the people's jury system have a great effect on judicial justice. This paper attempts to start from the internal connection between the People's Jury System and the judicial justice and combine the existing problems of the people's jury system to put forward the reform and improving direction on how to give better play to the people's jury system in strengthening the judicial justice and safeguarding the judicial justice.

\section{The CuRrent Problems of the PeOPLE'S JuRY SYSTEM}

\section{A. The Status of Jurors Is Unclear}

By examining the major legal states in the world today, we can see that there are two main categories of the existing jury system. One is the elite course of the civil law system, the other is the civilian course of Anglo-American Law. What is the elite course? It means that the jurors enjoy the same rights and responsibilities as the professional judges throughout the judicial process. They can participate in all stages of judicial case processing, not simply to identify the facts of the case but also put forward their own independent opinions on the law application problems involved in the case, not subject to the constraints and restrictions of the judge. The civilian course is very different, the jurors are only involved in the identification of the fact of the case, but do not put forward their own 
independent advice on the application of the law. At the same time, it needs to note that the judge can neither express their views on the facts of the case, and the status of jurors in court hearing is more passive, who generally will not dominate the trial. Since the inception, the status of China's people's jurors has been in a relatively vague state. Jurors can participate in legal affirmations, but many jurors also have legal expertise. But the good news is that the decision of the Fourth Plenary Session of the Eighth Central Committee pointed out to further clarify the position of jurors, who should only express their views on the fact of the case, but do not comment on the application of law. But in the actual operation, it is not so simple, problems like what the fact finding is and what is the law application are which difficult to distinguish in practice, and the fact finding of some cases is very complex, for example, the problem of key component in tort liability is a professional legal problem itself, not simply a matter of fact finding, it is a tradition of Anglo-American Law that the jurors just know the fact, a product of case law system, and our country has been implementing code law system. Different from the agnosticism, the philosophical foundation of case law, the philosophical foundation of the civil law system is knowability, and its tradition has always emphasized the democratization of the law rather than the elitism, emphasized that the law should be known to people, which can be seen from our practice of law popularisation, so it's in doubt whether the system isolation of jurors has the current system culture of our country. At the same time, the judge's law application is sometimes not entirely correct, so should an external monitoring force be removed during the panel discussion of a case, and hand over all the power of law application to the judge?

\section{B. The Power and Responsibility Are Vague}

The current People's Jury System does not make it clear whether all cases require the use of people's jurors, and the ambiguous statement of "great influence" is often used in the use of articles of law, without institutional constraints, and only a few courts will assess the participating ratio of people's jurors, at the same time, there is no provision on which specific procedure of the judicial case the jurors shall participate in. Many of the jurors in real life have not intervened in judicial cases before, for example, the people's jurors often do not participate in pretrial evidence exchange, so they have weak perceptual knowledge of the evidence. Pretrial evidence exchange is actually important in the trial practice, which can help the judge to form a preliminary evidence image. At the same time, it should be noted that because the people's jurors belong to outsiders, they are not very familiar with the judicial work, and sometimes they are every likely to make the same views with the judge under his or her guidance, and because their responsibilities are not clear, the motive force for them to insist on their own opinions is not very sufficient, which can refer to the status of independent directors in the listed companies in China, although the law gives them the same rights as the internal directors, they always become the tool of raising their hands in the actual operation of the company, if their legal responsibility is investigate afterwards, they say they are innocent. However, the original intention of establishing the independent directors is the same as the jury system, which is also to supervise insiders, but one is an internal director, and the other is the judge in the court. Therefore, the rights and responsibilities of the people's jurors should be further clarified, which should not only be embodied in the legal provisions, but also should be implemented in the trial process of the courts. For example, in the order of giving opinions, the jurors should give their opinions first rather than the judges. And in terms of determining the responsibility, they should be different from the judge, as long as they do not commit major faults, generally they do not have to be responsible, otherwise it may affect the enthusiasm of people's juror to participate in the trial, because the jury strictly work should belong to a volunteer work, which has no essential difference from the volunteers, and the responsibility of nongratuitous act shall not be same as the gratuitous act.

\section{The Judicial Function Is Not Clear}

The establishment of any system has its starting point, that is, what this system is established for in the end, which must be clear. As Milan Kundera once said, "We go too far to remember the destination at the time of departure". After the judicial reform, due to the implementation of the staff number system, the trial strength in the court is greatly reduced, and after the implementation of hierarchical system of filing case, the number of cases increase rapidly, so many of the courts want to take jurors as the replacing strength. This idea has a problem, fir the positioning of professional judges and jurors is not the same, which can not be confused. The juror system has its unique institutional value, which is supervision. People's juror is not only a manifestation of judicial openness, but also has a supervisory function. And we can even say that the purpose of openness is to monitor, the sunshine is the best corrosion remover. Here we specifically make clear the jurors' supervisory function, any act needs to be supervised, and there is no exception for the judge to exercise the right of examination and approval. But also in our country, jurors also bear an exceptional function, which is the popularity of justice. Justice should take the interests of the people as the primary consideration, but can not apply the articles of law mechanically, otherwise it becomes legal chauvinism.

\section{The Institutional CAuses of THE REALISTIC Flaws OF THE PEOPLE' S JURY SYSTEM}

\section{A. The Legislative Causes}

China's Constitution clearly carries out the allocation of judicial adjudication, and endows the people's courts with judicial power. While the National People's Congress's "Decision" has endowed the people's jurors with judicial power. This is actually a legislative conflict, and also from the legislative point of view, the National People's Congress's decision is not able to change the provisions of the Constitution. Comrade Xi Jinping pointed out that any reform should be in accordance with the law. Therefore, the NPC should revise the constitution and give it to the people's jurors. The judicial power should also study and formulate "People's Juror Law" to further clarify the position and responsibilities of jurors. 


\section{B. The Theoretical Study Is Not Sufficient}

People's Jury System is not yet mature, which still needs the demonstration and feedback of judicial practice. Practice is the sole criterion for testing truth, and any system design needs to be experienced in judicial practice. In the process of theoretical research, the academic circle should abandon the pure speculative research methods in the past, and actively absorb the excellent research methods of other disciplines, such as the empirical research methods in sociology, and carry out investigation and research more, only in this way can we get good research results.

\section{The Realistic Security Measures Are Imperfect}

On the one hand, it lacks scientific theoretical basis. The research on people's jury system is weak in the academic circle, and the existing research is often theoretical research, which lacks empirical research. On the other hand, the actual operation is difficult. After the judicial reform, with the gradual implementation of the staff number system, the number of trial judges in the courts has been further reduced, and the number of corresponding judicial auxiliary personnel has not been increased. Thus, the contradiction between more cases and less personnel is further prominent, and the proportion of jurors' appearance in court has increased greatly, which often forms a collegiate bench with only one judge, so the necessary of the reform of the jury system is enhanced greatly.

\section{Suggestions on Perfecting PeOPle's Juror SYSTEM UNDER THE BACKGROUND OF JUDICIAL JUSTICE}

\section{A. Modify the "Constitution", Formulate "People's Juror Law", Clarify the Legal Status of People's Jurors from the System}

If the name is not correct, the words will not ring true. If the words do not ring true, then it will not work. First of all, the Constitution should be modified to clearly endow the people's juror with the judicial power. At the same time, the mature experience of various areas after the judicial reform should be combined, and the system of "People's Juror Law" should be grasped to clarify the selection criteria and procedures of people's jurors and their power and responsibility during the judicial process. There should be an accurate perception of the function of the people's jurors, who should focus on the people, and emphasize the generalization of jurors, rather than take the elite course, and select some of the upper class in the community to serve as people's jurors. Colleagues should change the reality of predicament that the people's jurors "accompanying but not making a trial". At the same time, the dilemma where the people's jurors "accompany but not judge" in the past shall be changed. People's jurors can not just be a decoration, but should participate in the entire process of the trial, such as participating in the pretrial evidence exchange and out-of-court reconciliation. We must pay attention to the advantages of people's jurors, because now many parts of China are still in rural society, where there are many informal rules, and these informal rules may not be fully consistent with the provisions of the law, but play an important role in daily life. People's jurors come from the grassroots level, so they are often more familiar with these informal rules, and therefore more able to use them in the judicial process to achieve better social effects. Especially in the grass-roots courts, there is often great trial pressure, but now the people's courts lay special stress on the rate of ceasing litigation. So mediation has become an important procedure in the grassroots courts, and to give play to the mediation system, first of all it needs an authority figure. And some young judges often do not have this condition, and can not get recognized by the involved parties. People's jurors can do it. At the same time, mediation also needs to be familiar with the informal rules, and people's jurors have more advantages.

\section{B. Modify the Existing Qualification of the People's Jurors, Make It More Scientific and Standardized}

First of all, the existing qualifications take the education background as a selection condition of people's jurors. This is not correct, education can only represent a person's learning experience, but can not reflect a one's full capacity, although some people have not received higher education, they have very high EQ, who are suitable for people's juror. In practice, because China's higher education has always been a scarce resource and belonged to the selective examination, many excellent talents do not accept higher education, and in the actual judicial process, many parties have not received higher education, either, so there are many differences in some concepts, at this time, people with the same background of life are actually needed to participate in to persuade the parties to obey the legal resolution. And therefore the professional judges have often received higher education, and there are many concept divergences between the parties, which can exactly be made up by the people's jurors. Secondly, the existing age condition is too low, only 23 years old, which belongs to youth, with little life experience, and sometimes it's difficult for them to analyze the problems comprehensively and objectively. Thus the working age should be appropriately raised, and more attention should be paid to playing the role of retirees, for it's a part-time work for the in-service staff to participate in the review, so their enthusiasm of participation is not high. They often have their own work, but retirees are different, who do not their own work and can put all the energy into the people's jury, playing better roles. And the retirees often have rich experience and accumulation of life, which make them more convinced and authoritative. Thirdly, the number of people's jurors should be expanded. Jurors are randomly selected in the course of the case to prevent them from using their power for rent-seeking.

\section{We Should Give Full Play to the Innovation Measures of People's Jurors in All Levels of Courts, and Actively Sum up Good Experience}

In the course of the implementation of the People's Jury System, the local courts have done a variety of exploration and innovation to achieve the greatest judicial benefits. The author believes that these explorations are conducive to the improvement and development of the people's jury system. For example, Ji'nan Intermediate People's Court initiated the "hearing system" on June 9, 2015. The hearing system of the trial refers to the system in which a certain number of people 
from all walks of life are invited to form the hearing panel to audit the trial, and discuss together to assess the court trial procedure, vocational skills, judicial quality and mediation skills on the trial work and disposition of the case after the court and give professional advice. It is different from the jury system in the Anglo-American Law system and the civil law system. It is a new initiative for the people's court to realize the benign interaction between the independent exercise of judicial power and the external effective supervision, and to understand the new expectation of the public. The collegial bench shall exercise the judicial power independently according to the law, but the collegial bench shall pay attention to absorbing the opinions of the hearing panel during the panel discussion of the case. Firstly, the members of the hearing panel make one selection for each case, and the hearing cases will successively realize random selection; secondly, the members of the hearing panel make an independent and secret assessment on the case, and strict rules are made on avoidance and secrecy; finally, strictly standardize the hearing procedure, issue material related the case before the court, assess and draw the judicial verdict in time after the court. This system, I believe, is an innovative initiative which fully absorbs and learns from the successful experience of the two legal systems. To a large extent, it gets rid of the shortcoming of the people's jury system that the cost is high and the effect is low, but also inherits the advantages of the judicial activities that is open and transparent, and be supervised by the masses. The withdrawal of this system is not only the progress of the judicial openness of the court, but also the beneficial development and supplement of the people's jury system. Although the system is in the stage of exploration, trial and error with no perfect argument, we still have a good expectation to its maturity and development.

\section{CONCLUSION}

During the promotion of judicial justice in our country, the people's jury system is only one of the links. The establishment of judicial justice requires concerted efforts, multi-party collaboration, but not to just rely on the people's jury system. In the implementation of people's jury system, our country should strengthen the popularization of law to enhance the legal literacy of social citizens, enabling the law to win support among the people, the judicial justice to convince the public, and ultimately enhancing the country's judicial credibility.

\section{REFERENCES}

[1] Liu Xiqiu: "Study on the History of Jury System", Law Press, 2010 edition.

[2] He Jiahong: "Where Should China's Jury System Go", China University of Political Science and Law Press, 2006 edition.

[3] Song Bing: "Reader: the Judicial System and Judicial Proceeding of the United States and Germany", China University of Political Science and Law Press, 1999 edition.

[4] Yu Shutong, Xie Zhaohua: "French Criminal Procedure Code", China University of Political Science and Law Press, 1997 edition.

[5] Ji Jinhua: "the Authority of the Judiciary", Shandong People's Publishing House, 2004 edition. 